\title{
Carta a mi abuelo
}

\author{
Jorge UrRea Filgueira
}

\section{Querido abuelo:}

Una cosa que me gustaba mucho de tus visitas a Madrid, a menudo relacionadas con la Real Academia de la Historia, era que nos llevabas a una librería y nos comprabas un libro, gracias a lo que yo tomé amor por la lectura. Siendo yo un adolescente temprano, que ya había leído a Freud y Dostoyevsky, te pregunté qué debía leer y me dijiste que la Odisea; a lo que respondí, demasiado pagado de mí mismo, que ese ya me lo había leído, sin darme cuenta de que un libro así te acompaña siempre y, con cada edad, tiene distintas lecturas en profundidad y significado, muchas idas y venidas, como tú propia vida y las de todos nosotros.

Naciste fruto de la unión de vocaciones científica y sagrada, y decidiste destacar desde un tótem intelectual, referente para todos, incluso desde tu primera intervención en un periódico con tan solo 14 años. Como Ulises, tu viaje pasó por muchos puertos antes de llegar a Ítaca y volver. Así, tu enorme talla intelectual estaba respaldada por la humanidad del que enseña en el museo, en el congreso, en el instituto, en el coro, incluso apagando fuegos, pues como mi padre pensó en varias de sus visitas a tu casa al conocerte, eras bombero y habías "salido a apagar un fuego". Es decir, que como alcalde, no te quedabas en casa, dejando el trabajo para los bomberos, ibas en persona a arengar a los paisanos a defender lo que es de todos, como con la cultura y la política en cualquiera de sus dimensiones y colores, porque es de todos. Un hombre de Estado, ciudad y aldea como ya no hay o yo conozco, lamentablemente.

Tal fue tu talla, que aunque muchos hablan, no creo que nadie sea capaz de abrazarla para delimitarla. Tantas ramas del saber y la cultura, las culturas, nacional, regional, internacional... Todo te interesaba y de todo sabías. Pocos días antes de morir, yo te leía en voz alta uno de tus cinco periódicos a instancias tuyas, buscando alguna noticia de interés, sin que sinceramente a mí me interesara mucho las pequeñas anécdotas locales, pero mi manera de leerlo tan desafectado hizo que tú me pidieras que parara. Tú incluso moribundo, estabas en otro nivel, de mente y de corazón, como pálpito de corazón, y como inquietud mental a la que dar solución, con corazón.

Algunas voces, pocas, dicen que en las relaciones no fuiste tan prolijo como en lo intelectual, pero la verdad es que en lo social siempre tuviste humildad cercana e interés verdadero por lo que le pasaba a los demás, tratándolos por sus nombres en medio de la calle, de paseo hacia el museo, donde te paraban a preguntarte cosas con verdadero amor admirativo. En lo familiar, nuestras partidas de ajedrez siendo yo niño eran muy divertidas y fuera de ellas, la abuela siempre conectó tu corazón y cabeza con todos nosotros, sabiendo siempre de nosotros "en tiempo real". La confirmación me llegó el día de tu funeral, en que tu chófer, tu taxista de siempre, me preguntó por enfermedades mías de las que nunca tuve idea que tú supieras, y que no solo sabías sino que compartías preocupación con tu persona de confianza y compañía en tantas idas y venidas.

Acabo compartiendo aquí un extracto de una carta que me escribiste, viviendo yo en Londres, en la que me decías «lo mucho que echo de menos a María Teresa tras su muerte». No me hablabas de ir a ser doctor honoris causa, ni conselleiro de cultura, ni tantas otras cosas; me hablabas de tu compañera, gran mujer en la sombra, que a todos nos iluminó y sigue iluminando.

Desde mi propia Odisea, os sigo como modelos, y os quiero y echo mucho de menos a los dos.

Jorge Urrea Filgueira 